\title{
Overview of Bamboo Preservation Methods for Construction Use in Hot Humid Climate
}

\author{
Athiyyah Harivi Putri' ${ }^{1}$, Ova Candra Dewi ${ }^{1}$ \\ ${ }^{1}$ Department of Architecture, Faculty of Engineering, Universitas Indonesia, Indonesia \\ ova.candewi@ui.ac.id
}

\begin{abstract}
Indonesia is located in a hot, humid climate, and one of the abundant and indigenous natural resources in Indonesia is bamboo plants. People in everyday life widely use bamboo. However, the community has not been adequately educated about bamboo, especially in terms of (1) processing, (2) preserving, and (3) maintaining bamboo. These three things have essential roles in supporting the bamboo's durability since bamboo is susceptible to destructive organisms. In this study, the durability of bamboo was observed, interviewed, and analyzed to examine the most optimal bamboo preservation method for construction use in a hot, humid climate. The type of bamboo and the characteristics of bamboo were assessed: both by chemical and traditional methods of preservation. This study found that in terms of durability, the traditional preservation method results in stronger durable bamboos. The traditional methods are considered to be more optimal for bamboo building construction in a hot, humid climate.
\end{abstract}

(C) 2020 IJBESR. All rights reserved.

Keywords: Bamboo, preservation, construction use, hot humid climate

\section{Introduction}

Indonesia is located in a hot, humid climate, and one of the abundant natural resources in Indonesia is bamboo plants. Indonesia is a region that has a hot, humid climate and relatively high humidity. Among the regions with hot, humid weather are the regions of Southeast Asia countries whose position is almost or even crossed by the equator. These countries have a tropical climate that is warm and sunny during the summer. Generally, bamboos are found in the open space. Bamboos live in clusters, and they have joints and knuckles. Every joint has its branches [1]. Bamboo is one of the economic plants which can easily be found in people's garden and the villages [2].

Bamboo has benefits for the environment. Bamboo could be used as a water purifier for the riverbank area [3]. Furthermore, in socialcultural life, people use bamboo in a traditional ceremony, wedding ceremony, and musical instruments [4].

Bamboo has natural aesthetics, and it makes the use of bamboo as a material increases significantly. It is essential to think about the preservation and maintenance of the bamboo before its utilization or application, to consider its appropriateness as a material. The study intended to observe the most optimal method in preserving bamboo, especially on the durability to be used for construction in a hot, humid climate.

The utilization of bamboo could be found easily in Indonesia. However, not many have studied the preservation of bamboo. This study aims to observe the method of bamboo preservation in Indonesia and find out how the environment and living things deal with damage to the bamboo in a hot, humid climate. Therefore, the question of this study is, "what is the most 
optimal method in bamboo preservation for construction in a hot, humid climate?".

\section{Material and Methods}

The data was collected through in-depth observation of various bamboo preservation methods carried out by two bamboo industries. These methods were used in relevance to a hot, humid climate.

\subsection{Theoretical Review}

\subsubsection{Bamboo in Indonesia: Characteristic, Utilization and Type of Bamboo}

Bamboo in Indonesia is very easy to find in open places; living in clumps have segments and books [1]. In the year 2000, the area of bamboo plants in Indonesia was estimated to be $2,104,000$ ha consisting of 690,000 ha in forest areas, and 1,414,000 ha in areas outside the forest [6]. People in rural areas widely use bamboo because it is one of the most economical plants [2]. Bamboo can grow at a height of $15-18 \mathrm{~cm}$ per day and reach maximum height in 4-6 months. The cosmopolitan nature of bamboo makes it survive in all weather, both in hot and cold regions, in lowland cliffs [5]. In the construction field, bamboo, which has strong and hard stems, plays an essential role in the life of rural communities in Indonesia. The growth of bamboo takes 3-5 years to be used as a construction material. It is faster compared to wood, which takes 10-30 years [4].

Approximately 1,000 species of bamboo, around 200 species from 20 genera were found in Southeast Asia, whereas in Indonesia, about 60 species of bamboo were found [6]. Figure 1 shows the spread mapping of bamboo types in Indonesia. From 189 varieties of bamboo identified, only four are commonly used as construction materials. For example, in West Java, there are rope bamboo, gombong bamboo (Gigantochloa pseudoarundinacea), haur bamboo (Bambusa tuldoides and Bambusa vulgaris Schard.), and black bamboo. Each of them has its characteristics, sizes, and dimensions. As a result, their utilizations should give attention to each site-specific characteristic [7]. Some bamboos often used for construction are Petung bamboo (Dendrocalamus asper) and Apus bamboo (Gigantochloa apus). Both are spread all over Indonesia. Petung bamboo excels in durability, while Apus bamboo excels in flexibility[4]. Those are the primary considerations why both are used in building constructions.

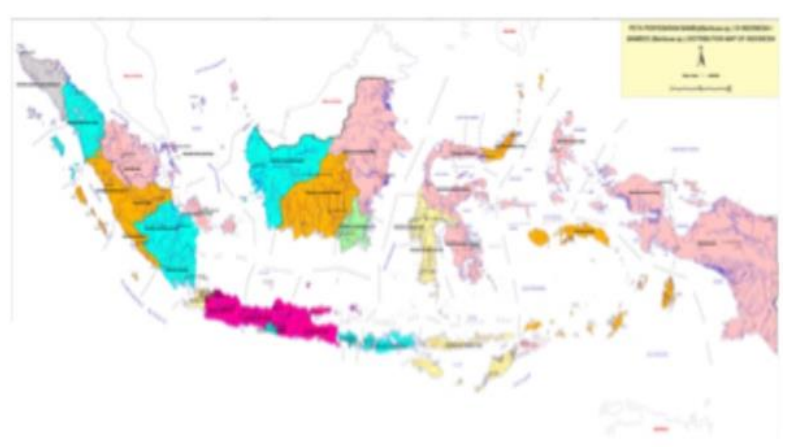

Figure 1: The Map Bamboo Distribution in Indonesia Source: (Bamboeindonesia, 2006)

As an example, Apus Bamboo is planted on the river bank, village border, and the slope of the hill (Figure 2). The purpose of Apus Bamboo planting is for construction materials, households, furniture, and ropes [6]. It also could maintain the stabilization of hydrology circles around the surrounding environment [8]. Apus Bamboo is also known as the type of big bamboo with under stem diameter up to 26 $\mathrm{cm}$ and height up to $25 \mathrm{~m}$ [9].

Apus Bamboo is a durable bamboo with short joint distance, but it has a thick bark [10]. Apus Bamboo also has a more significant stem than other bamboo types. Apus Bamboo shoot is usually used for food ingredients while the stem is used for construction due to its size and thickness [11]. Naturally, Apus Bamboo is spread all over Indonesia, from Sumatra, Java, 
Borneo, Sulawesi, Bali, Lombok, Nusa Tenggara islands to Maluku.

Petung bamboo grows in the high land, hill area, and wet weather. Petung bamboos are commonly used for poles or building supports, materials for pulp and paper industry, plywood, furniture, cane work, farming tools, and husbandry [9].
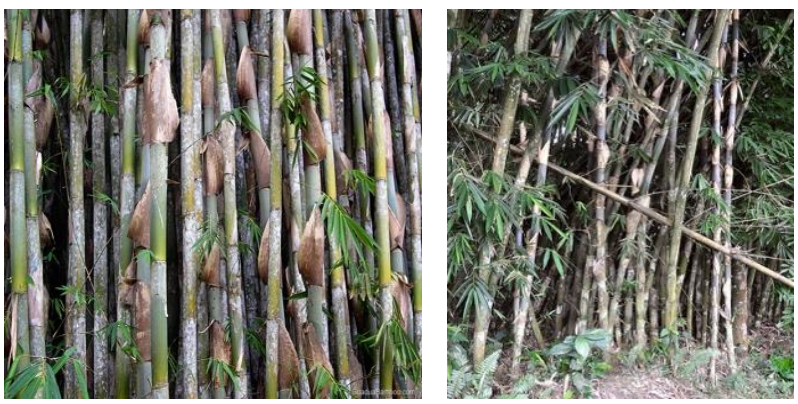

Figure 2:Apus Bamboo (left) \& Petung Bamboo (right) Source: (Wikipedia and guaduabamboo, 2015)

\subsubsection{Bamboo Preservation Methods}

Many variables affect bamboo's strength, including maturity, the season when it is harvested, and the treatment applied after the bamboo harvest. Bamboo preservation has often been carried out to increase bamboo durability in both traditional and modern ways [12]. Bamboo without preservation and protection from the environment and the weather can only last for around 1-3 years if it deals directly with organisms [13]. Bamboo that is dried before preservation will produce better quality and durability than the wet one with high water content [14]. There are two types of preservation methods, namely nonchemical methods (traditional) and chemical methods (modern) [15].

\section{a. Traditional or Non chemical Preservation of Bamboo}

People in Indonesia have been familiar with traditional methods of soaking bamboo in water for a long time (Figure 3). Preservation of bamboo using traditional methods such as soaking bamboo in both running and still water has been carried out by rural communities [16]. This method aims to reduce starch in bamboo, and it is applied to bamboo, which will be used as building materials. Soaking bamboo in water is not recommended to exceed 30 days [17].
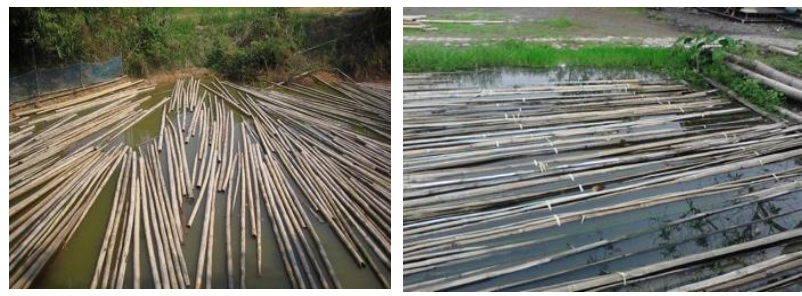

Figure 3: Traditional Bamboo Preservation with Water Soaking Source: (Radarcirebon.com, 2016)

Soaking bamboo in the water can reduce the level of bamboo starch. Therefore, the bamboo is less likely to be attacked by powder beetles, damaging the bamboo [18]. The decrease in starch content can also increase the strength of the bamboo [19]. Furthermore, this preservation is considered complete when the color of the bamboo is pale (not yellow, green, or black), and it has a characteristic of acidic odor [10]. Traditional methods result better in bamboo's strength [3].

\section{b. Modern or Chemical Preservation of Bamboo}

There is an easy way to preserve bamboo with a very economical cost, namely the gravity method (Figure 4) [20]. It is a simple chemical method that utilizes the force of gravity. This simple method makes it so that the range for bamboo preservation is unlimited [20]

Chemical methods are relatively expensive, but they result in better surface protection [17]. Currently, the use of chemical preservatives to increase the resistance of bamboo to termite attacks has often been done. Although this method effectively increases bamboo's 
durability, the use of chemicals faces obstacles because they are harmful to health and the environment [12]. This method's success depends on the accuracy of the concentration of the preservative solution given. Some of the known chemical methods of bamboo preservation are the Butt Treatment method, the open tank method, the Boucherie method, and fumigation (with methylbromide compounds). Chemical methods on a large scale are widely used in India, Taiwan, and Japan. Simple chemical methods are more appropriate in villages located far from the industrial center [17].

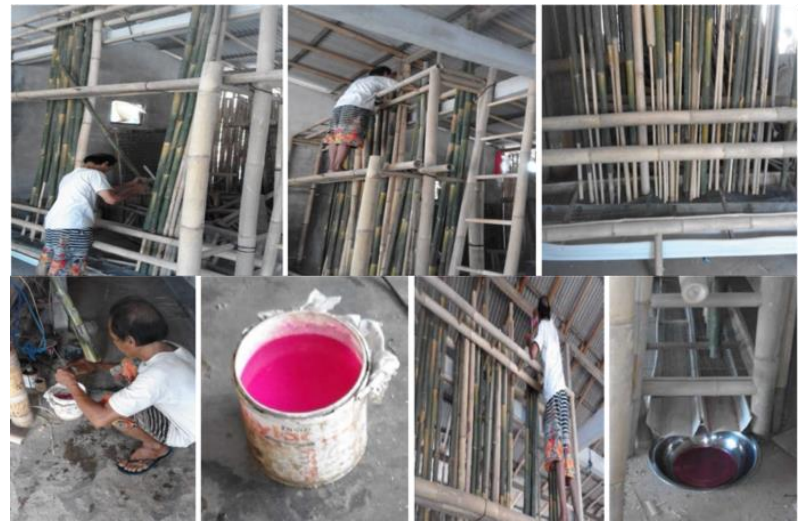

Figure 4: Bamboo Preservation with Chemical Methods Source: (Mengabdi, 2017)

\subsubsection{Bamboo for Construction Use}

In terms of the use of construction, bamboo is commonly found in various types of buildings. Bamboo is a renewable and multifunction material [21]. It is shown by its high strength and low weight volume. It is also easy to handle with simple tools, so the awareness of using it is very high. Bamboo is a part of people's life in Indonesia, especially in the village where it is one of the most favorite building construction materials [21]. It is used for pole, wall construction, rope construction, and floor construction [22].

There are three types of techniques used in construction, namely: (1) woven techniques, (2) vertical techniques,
(3). pelupuh techniques Each method has entirely different durability depending on their preservation and maintenance. These three techniques use either bamboo skin or the inside of bamboo as the primary material.

a. Woven technique connects bamboo blades or tutu, so it does not escape each other. It stresses at the cross point, which results in high friction without changing the shape of the webbing [10]. There are various bamboo woven techniques, namely braid plait, straight plait, and batik plait (Figure 5).
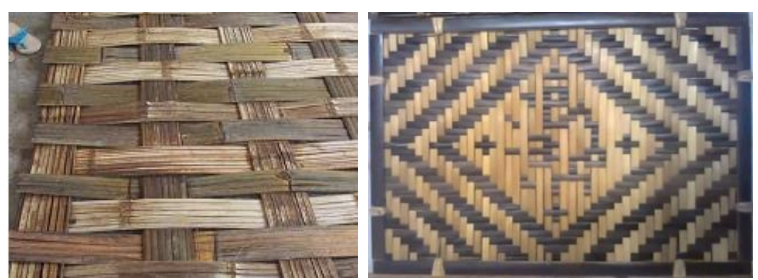

Figure 5: Bamboo Construction with Woven Technique Source: (Bernas.id and personal documentation, 2016)

b. Vertical or stacking technique is an ancient way that arranges the whole stems of bamboo vertically or horizontally (Figure 6). It uses an entire round bamboo shaped like a pipe, so this technique is considered more straightforward than the others, and it is widely used. The assemblage is done vertically and horizontally to equalize the burden received [10].
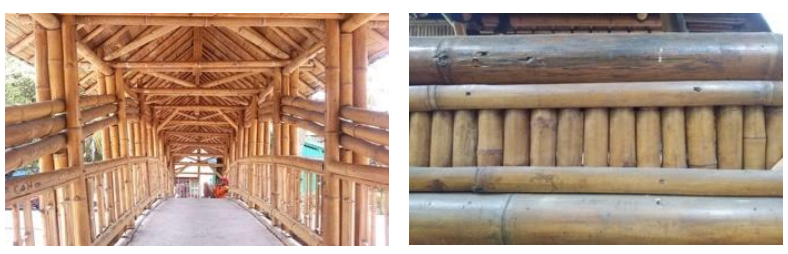

Figure 6: Bamboo Construction with Vertical Technique Source: (Properti.kompas, 2018)

c. Pelupuh or splitting technique is the process of cutting bamboo segments using an axe or machete. This process starts with dividing the whole bamboo stem on one side, and then the gap is stretched. Figure 7 is an example of bamboo use using a pelupuh technique, which 
is then woven. There is also a bulkhead in the cavity of each segment, which will be removed until the bamboo culm wall can be hit and flattened into a pelupuh [10].
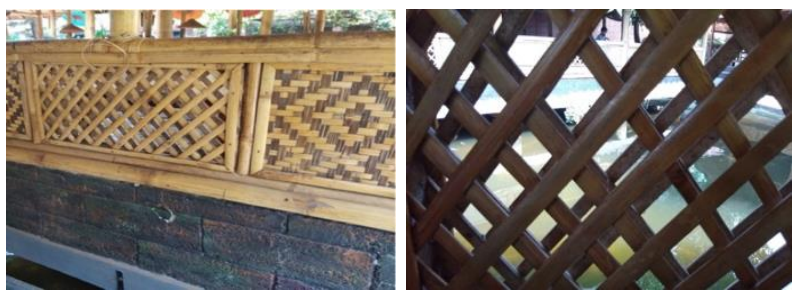

Figure 7: Bamboo Construction with Pelupuh Technique

Source: (Personal documentation, 2019)

\subsubsection{Damage Factors of Bamboo}

The durability of bamboo includes bamboo's resistance to various factors that can destroy bamboos, such as termites, dry wood powder, and bamboo destroyer fungus (Phallus indusiatus) [23]. The causes of bamboo damage are also various, but there are two leading causes of bamboo damage: biological and nonbiological.

\section{a. Biological Factors}

Causes of biological bamboo damage are termites, powder beetles, and fungi (Figure 8). Some of the fungi are Schizophlyllum cummune, Auricalria sp; Pleurotus sp; Strureum sp; and Poria incrssata sp [24]. Fungi that attack bamboo will cause damage such as weathering and discoloration of the bamboo, as well as impurities on the skin of the bamboo [17]. Bamboo fiber tissue can sustain the life of the powder beetle by providing starch.
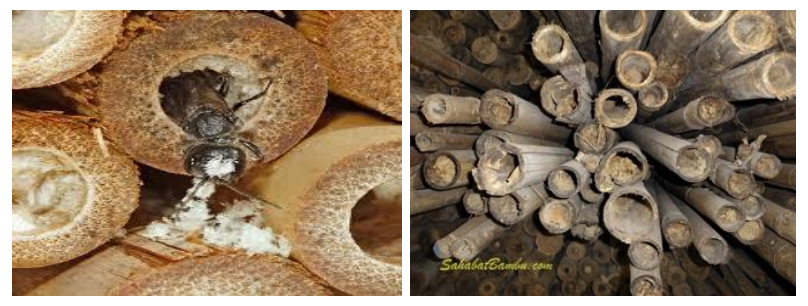

Figure 8: Biological Factors of Bamboo Damage Source: (Baltyra, 2013)
Therefore one of the purposes of preserving bamboo is to remove the starch, which causes the powder beetle to live and develop [24].

\section{b. Non-Biological Factors}

The non-biological factors which can significantly damage bamboos are weather and environmental conditions-water is one of them. Bamboo with high water content will decrease in its strength, which causes it to rot more quickly [25]. Bamboo that does not pass any preservation treatments and not protected by the weather will only last for about 1-3 years. Unlike bamboo, which is protected from the weather, it can last for 4-7 years [17]. Especially for bamboo building construction, if placed in an ideal environment, it can last for $10-15$ years [25].

\subsection{Observation Objects}

In this study, the authors did not conduct any preservations for the bamboos. Instead, the authors observed the preservation process done by the two bamboo industries in Indonesia. The bamboo industries used as observation objects are The Indonesian Bamboo Foundation and Nusantara Bamboo Academy. Aside from observation, the researcher also conduct indepth interviews with experts in the industries.

The first observation object is The Indonesian Bamboo Foundation, one of the largest bamboo foundations in Indonesia. The owner of the foundation is H. Jatnika Nanggamihradja or who is familiarly called Abah Jatnika. He established the Indonesian Bamboo Foundation in 1995. It is located in Cibinong, West Java, with an area of approximately 11 ha. 


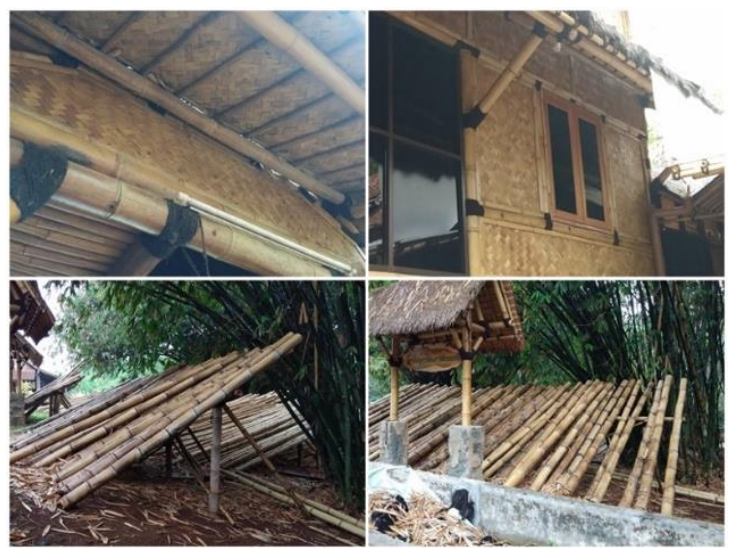

Figure 9: The Indonesian Bamboo Foundation Source: (Personal documentation, 2019)

The Indonesian Bamboo Foundation has various Indonesian bamboo types: from a petung bamboo, a rope bamboo to a honey bamboo (Figure 9). With the diversity of bamboo species owned, the bamboo preservation and processing carried out in this industry are very supportive, making it one of the best options for further study. The Indonesian Bamboo Foundation has built approximately 8,000 homes in 26 countries.

The second observation object is Nusantara Bamboo Academy, a bamboo industry that has been engaged in bamboo for a long time. It is located on Jalan Cendekia, Ciater, Serpong, South Tangerang, Banten 15310. Nusantara Bamboo Academy participates in the processing and preservation of bamboo, widely used in building construction, handicrafts, and furniture. Nusantara Bamboo Academy often educates visitors about bamboo matters, specifically about how to maintain bamboo and the benefits that come from bamboo. The founder of this industry is Muqoddas Syuhada.

The bamboos owned by Nusantara Bamboo Academy are quite diverse. Most of their bamboo products are already in the form of handicrafts and building elements. They use apus bamboo and petung bamboo as materials for their products. The bamboo products are various kinds of crafts, hats, or bags that have been exported abroad. Their bamboo can be seen in many industrial buildings because using bamboos as a material is economically beneficial [2]. Nusantara Bamboo Academy workers process bamboo together and use it together so that the bamboo has social values as well (Figure 10).

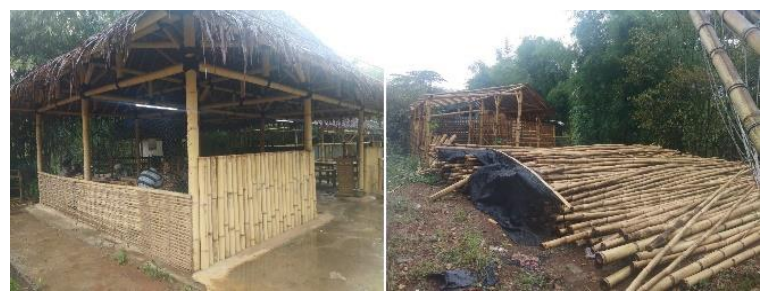

Figure 10: Nusantara Bamboo Academy Source: (Personal documentation, 2019)

\subsection{Research Parameters}

The study observed the preservation methods used by both observation objects. There are 5 five parameters used, namely: the media, the duration of preservation, the signs of the preservation being done (the odour or the color of the bamboo), the type of the bamboo preserved, and the durability of the bamboo after preservation.

\section{Results and Discussions}

\subsection{The difference of presevartion methods used by the two observation objects}

The study observed the preservation methods used by both observation objects. The Indonesian Bamboo Foundation does not use chemical processes to preserve their bamboo because it is considered inefficient and unsatisfactory (table 2). In contrast, Nusantara Bamboo Academy uses both traditional techniques and gravitational chemical methods for their bamboo preservation processes. Nusantara Bamboo Academy doesn't have the same belief for the chemical preservation method because, according to them, it is more efficient in terms of time. Table 1: The observation subjects' on traditional preservation methods 
p-issn: 2581-1347 | e-issn: 2580-2607 | Pg. 1-10

\begin{tabular}{|c|c|c|}
\hline $\begin{array}{c}\text { Traditional } \\
\text { Method } \\
\text { Parameters }\end{array}$ & $\begin{array}{c}\text { The Indonesian } \\
\text { Bamboo } \\
\text { Foundation }\end{array}$ & $\begin{array}{c}\text { Nusantara } \\
\text { Bamboo } \\
\text { Academy }\end{array}$ \\
\hline $\begin{array}{c}\text { Preservation } \\
\text { Media }\end{array}$ & Pond & River \\
\hline $\begin{array}{c}\text { Preservation } \\
\text { Duration }\end{array}$ & $1-2$ months & 30 days \\
\hline $\begin{array}{c}\text { The signs of the } \\
\text { preservation } \\
\text { being done }\end{array}$ & $\begin{array}{c}\text { The bamboo } \\
\text { odour resembles } \\
\text { that of a thick } \\
\text { vinegar }\end{array}$ & -- \\
\hline Bamboo Types & $\begin{array}{c}\text { All types of } \\
\text { bamboo }\end{array}$ & $\begin{array}{c}\text { All types of } \\
\text { bamboo }\end{array}$ \\
\hline $\begin{array}{l}\text { Bamboo's } \\
\text { Durability }\end{array}$ & $10-20$ years & $10-20$ years \\
\hline
\end{tabular}

Source: (Author, 2019)

Table 2: The observation subjects' on chemical

\begin{tabular}{|c|c|c|}
\hline $\begin{array}{c}\text { Chemical } \\
\text { Method } \\
\text { Parameters }\end{array}$ & $\begin{array}{c}\text { The Indonesian } \\
\text { Bamboo } \\
\text { Foundation }\end{array}$ & $\begin{array}{c}\text { Nusantara } \\
\text { Bamboo } \\
\text { Academy }\end{array}$ \\
\hline $\begin{array}{c}\text { Preservation } \\
\text { Media }\end{array}$ & - & Gravity system \\
\hline $\begin{array}{c}\text { Preservation } \\
\text { Duration }\end{array}$ & - & $7-14$ days \\
\hline $\begin{array}{c}\text { The signs of the } \\
\text { preservation } \\
\text { being done }\end{array}$ & - & -- \\
\hline $\begin{array}{c}\text { Bamboo Types } \\
\text { Bamboo's } \\
\text { Durability }\end{array}$ & - & $\begin{array}{c}\text { All types of } \\
\text { bamboo }\end{array}$ \\
\hline
\end{tabular}

Source: (Author, 2019)

For the traditional method, the one that distinguishes between the two is the water body used to soak their bamboo. The Indonesian Bamboo Foundation uses a pond, while Nusantara Bamboo Academy uses a river, which is considered more effective based on its size (Table 1). The gravity method used by the Nusantara Bamboo Academy is following the theory from Simpen [26]. The researcher also got additional information that the gravity method only requires 7-14 days at most, which is faster than the traditional preservation method.

\subsection{The advantages and disadvantages of Traditional and Chemical methods}

The study also compared the advantages and the disadvantages of both preservation methods. The theory regarding two preservation methods will be the basis for comparing the advantages and the disadvantages of two methods (Table 3).

Table 3: The advantages and disadvantages of Traditional and Chemical preservation methods

\begin{tabular}{|c|c|c|}
\hline Methods & $\begin{array}{c}\text { Traditional } \\
\text { Method }\end{array}$ & $\begin{array}{l}\text { Chemical } \\
\text { Method }\end{array}$ \\
\hline \multirow{5}{*}{ advantages } & $\begin{array}{l}\text { Add the bamboo's } \\
\text { strength }\end{array}$ & $\begin{array}{l}\text { The process only } \\
\text { takes up to } 7-14 \\
\text { days }\end{array}$ \\
\hline & $\begin{array}{l}\text { Clean the bamboo } \\
\text { and protect the } \\
\text { bamboo from pests }\end{array}$ & $\begin{array}{l}\text { The bamboo can } \\
\text { immediately be } \\
\text { used after the } \\
\text { preservation } \\
\text { process }\end{array}$ \\
\hline & $\begin{array}{l}\text { It is a cultural } \\
\text { tradition that is } \\
\text { need to be } \\
\text { preserved }\end{array}$ & \\
\hline & $\begin{array}{l}\text { The processing is } \\
\text { simple and }\end{array}$ & \\
\hline & $\begin{array}{l}\text { Produce stronger } \\
\text { and more durable } \\
\text { bamboos }\end{array}$ & \\
\hline \multirow{3}{*}{ disadvantages } & $\begin{array}{l}\text { The process can } \\
\text { take up to more } \\
\text { than } 30 \text { days }\end{array}$ & $\begin{array}{l}\text { Does not add } \\
\text { strength to the } \\
\text { bamboo }\end{array}$ \\
\hline & $\begin{array}{l}\text { There are a lot of } \\
\text { steps need to be } \\
\text { done before and } \\
\text { after the } \\
\text { preservation } \\
\text { process }\end{array}$ & $\begin{array}{l}\text { Need a certain skill } \\
\text { to be done }\end{array}$ \\
\hline & $\begin{array}{l}\text { The bamboo gives } \\
\text { out an } \\
\text { uncomfortable } \\
\text { odour }\end{array}$ & $\begin{array}{l}\text { Produce weaker } \\
\text { and less durable } \\
\text { bamboo }\end{array}$ \\
\hline
\end{tabular}

Source: (Author, 2019)

The two bamboo industries have stated that the most optimal method for preserving bamboo used for wall construction is the traditional water soaking method. The traditional method is indeed much easier to do and does not require a lot of costs and has proven its durability. However, this method also requires a long time to complete (30 days) and depends on the respective parameters and water used during the preservation process. After the preservation process, the bamboo can not be directly used. It has to go through several more stages, namely bamboo drying, cleaning, and coating. These 
after-preservation processes are also carried out by both bamboo industries to ensure the most optimum bamboo quality.

The disadvantages of the chemical methods are that they have to build a tower which is made following the length of the bamboo. Then the bamboo liquid used must also be prepared through a distillation process. The cost is also more expensive than traditional methods. Most importantly, the chemical gravity method only cleans and keeps the bamboo away from pests; it neither changes the shape of the bamboo nor adds strength to the bamboo. However, the gravitational chemical method can be done in only 7-14 days, which is more time-saving than the traditional immersion method.

\subsection{The effect of Humidity on Bamboo Damage}

Bamboo is adaptive to the water environment, making it able to maintain its durability and strength in construction. Indonesia has a hot, humid climate, it is essential to consider the type of bamboo, and the preservation method used [27].

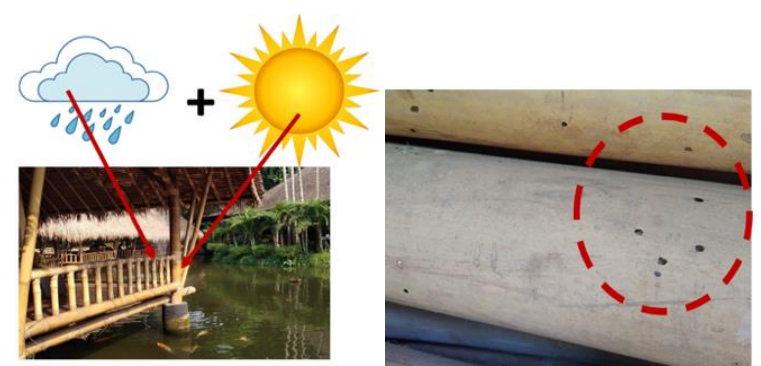

Figure 11: Example of Non-Biological Damage in Bamboo Construction

Source: (Personal documentation, 2019)

Petung Bamboo and Apus Bamboo are the two types of bamboo commonly used for construction in Indonesia. In terms of preservation, the concern is cheap and easy to get and friendly to the environment [12]. As bamboo gets older, its water content decreases so that it becomes more challenging to preserve bamboo. Therefore chemical methods are better applied in the rainy season as more water available [17]. Figure 11 shows one of the approaches to adapt to a hot, humid climate. The bamboo should be covered with waterproofing material to protect nonbiological damage.

\section{Conclusion}

Bamboo has many benefits, which should continue to be preserved in the field of architecture. Bamboos that are used for construction must go through a preservation process before being applied. The parameters that determine the quality and the age of the bamboo are the type of bamboo used, the method of preservation carried out, and also the maintenance to keep the bamboo away from undesirable damage.

The bamboo preservation method is divided into two methods, namely traditional methods, and chemical methods. In terms of productivity, the chemical method is more productive because it can be done quickly, so it can preserve bamboo in large quantities. However, in terms of durability, the traditional process results in more reliable and more durable bamboo. Traditional methods are considered to be more optimal for the bamboo building construction in a hot, humid climate.

\section{Acknowledgement}

The authors would like to thank The Indonesian Bamboo Foundation and Nusantara Bamboo Academy for the insightful discussions.

\section{References}

[1] Yani AP. Keanekaragaman Bambu dan Manfaatnya Di Desa Tabalagan Bengkulu Tengah. J. Gradien 2014;10:987-91

[2] Sulistiono KI, Nugraha A. Keanekaragaman jenis bambu dan pemanfaatannya di kawasan hutan Gunung Tilu Desa Jabranti Kecamatan Karangkencana Kabupaten Kuningan. Wanaraksa 2016;10:41-7

[3] Nanggamihradja J. Serumpun Bambu Sejuta Karya. Yayasan Senam Hijaiyah Indonesia (YSHI); 2012

[4] Widnyana K. Bambu Dengan Berbagai Manfaatnya 


\begin{tabular}{ll}
\hline Bumi Lestari 2008;8:1-10 & Info Tek. EBONI 2016;13:79-92 \\
[5] Arsad E. Teknologi Pengolahan Dan Manfaat Bambu. & [26] Simpen IN. Teknologi pengawetan ramah \\
J. Ris. Ind. Has. Hutan 2015 & $\begin{array}{l}\text { lingkungan untuk pengerajin bambu tradisional } \\
\text { [6] Dransfield S, Widjaja EA. Plant Resour. South-East }\end{array}$ \\
berorientasi ekspor di desa belega gianyar. 2017;16:185- \\
Asia No.7 Bambos. Backhuys Publ. no.7; 1995 & 192 \\
[7] Handoko EB, Maurina A, Budianastas, Gustin R, & [27] Naing N. Rumah Mengapung Suku Bugis. Nuansa \\
Sudira B, Priscilla J. Peningkatan Durabilitas Bambu & Cendekia;2018
\end{tabular}

Sebagai Komponen Konstruksi Melalui Desain

Bangunan dan Preservasi Material 6; 2015

[8] Rahmawati R, Baharuddin B, Putranto B. Potensi Dan Pemanfaatan Bambu Tali (Gigantochloa apus) DI DESA LEU KECAMATAN BOLO KABUPATEN BIMA. Perennial 2019;15:27

[9] Eskak E, Paramadharma H. Hand Jigsaw; 2012

[10] Frick H; 2004 No Title

[11] Rini DS. Sifat Fisika Bambu Petung (Dendrocalamus asper (Schult. f.) Backer ex Heyne) dari KHDTK (Kawasan Hutan Dengan Tujuan Khusus) Senaru Berdasarkan Posisi Aksial. J. Belantara 2018;1:101-6

[12] Rofaida A. Pemanfaatan ekstrak daun mimba ( Azadirachta Indica ) sebagai bahan. 2016;3:15-25

[13] Liese W. ed A GilesLesard; 1980

[14] Z C Budidaya Bambu Jenis Komersial; 2014

[15] Sulistyowati CA. Pengawetan Bambu. Teknol. Wacana - Pus. Inf. Teknol. Terap. ELSPPAT 1997;6:113

[16] Hamzah N, Pujirahayu N, Tama SR. Pemanfaatan Boraks Untuk Pengawetan Bambu Betung (Dendrocalamus asper Backer) Terhadap Serangan Rayap Tanah (Captotermes curvignathus). Ecogreen 2016;2:131-6

[17] Bagus IGL. Struktur dan Rekayasa Bambu; 2017

[18] AS. Petunjuk Ilm. Pengawetan Bambu Tradis. dengan perendaman Dalam Air Int. Dev. Res. Cent. Ottawa, Canada Yance; 1983

[19] Aini N, Bahan B, Puslitbang B, Puslitbang P, Departemen P, Umum P. Pengaruh Pengawetan Terhadap Kekuatan Dan Keawetan Produk Laminasi Bambu. Civ. Eng. Forum Tek. Sipil 2009;19:979-986

[20] Pathurrahman. Pengawetan Bamby dengan Cara gravitasi Pengawetan Bamby dengan Cara gravitas; 2000

[21] Komang N, Artiningsih A. Pemanfaatan Bambu Pada Konstruksi Bangunan Berdampak Positip Bagi Lingkungan. Metana - Media Komun. Rekayasa Proses dan Teknol. Tepat Guna 2012;8:1-9

[22] Sukawi. Bambu sebagai alternatif bahan bangunan dan konstruksi di daerah rawan gempa. 2010;10:1-10

[23] ELSPPAT T. Pengawetan Kayu dan Bambu. Puspa Swara; 2000

[24] Irawan P, Sukania W. Kekuatan Tekan dan Flexural Material Komposit Serat Bambu Epoksi. J. Tek. Mesin 2013;14:59-63

[25] Lempang M. Pengawetan Bambu Untuk Barang Kerajinan Dan Mebel Dengan Metode Tangki Terbuka. 
(This page is intentionally left blank) 